\title{
The effect of Aspergillus niger as a dietary supplement on blood parameters, intestinal morphology, and gut microflora in Haidong chicks reared in a high altitude environment
}

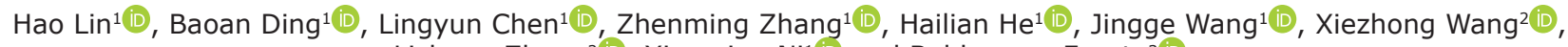 \\ Licheng Zhang ${ }^{2}$, Xiaoming $\mathrm{Ni}^{1}(\mathbb{D})$ and Baldassare Fronte ${ }^{3}(\mathbb{D}$ \\ 1. State Key Laboratory of Plateau Ecology and Agriculture, College of Agriculture and Animal Husbandry, Qinghai \\ University, Xining 810016, China; 2. Qinghai Animal Disease Control Center, Xining 810001, China; 3. Department of \\ Science Veterinary, University of Pisa, Viale delle Piagge 2, 56124, Pisa, Italy. \\ Corresponding author: Baoan Ding, e-mail: dingbaoan1967@aliyun.com \\ Co-authors: HL: 974274692@qq.com, LC: 1492101242@qq.com, ZZ: 2780612206@qq.com, \\ HH: 2505438527@qq.com, JW: 523496103@qq.com, XW: 491999098@qq.com, LZ: 381452822@qq.com, \\ XN: 33935500@qq.com, BF: baldassare.fronte@unipi.it \\ Received: 24-07-2020, Accepted: 18-09-2020, Published online: 23-10-2020
}

doi: www.doi.org/10.14202/vetworld.2020.2209-2215 How to cite this article: Lin $H$, Ding $B$, Chen $L$, Zhang $Z$, He $H$, Wang J, Wang X, Zhang L, Ni X, Fronte B (2020) The effect of Aspergillus niger as a dietary supplement on blood parameters, intestinal morphology, and gut microflora in Haidong chicks reared in a high altitude environment, Veterinary World, 13(10): 2209-2215.

\begin{abstract}
Aim: The effects of the inclusion of Aspergillus niger in the diet of Haidong chicks reared in the Qing-Zang high altitude area (China) under hypoxic conditions.

Materials and Methods: A total of 720 Haidong chicks were randomly divided into six groups and fed diets supplemented with $0 \%, 0.5 \%, 0.75 \%, 1.0 \%, 1.25 \%$, and $1.5 \%$ of $A$. niger to determine blood parameters, intestinal morphology, and gut microflora in Haidong chicks reared in a high altitude environment.

Results: Packed cell volume (PCV), red blood cell (RBC) count, white blood cell count, and hemoglobin concentration increased in the groups fed diets containing A. niger. The administration of A. niger in $1.0 \%$ and $1.25 \%$ significantly decreased the concentration of Escherichia coli in the cecum, while the concentration of Bifidobacterium and Lactobacillus in the cecum and ileum was increased in the treated groups. When compared to the control groups, villi height, crypt depth, and goblet cell density in the intestine was raised, in general, in the groups treated with $\mathrm{A}$. niger.
\end{abstract}

Conclusion: These findings suggest that $1.25 \%$ A. niger as dietary supplement may improve the resistance to ascites among birds reared under hypoxic conditions.

Keywords: Aspergillus niger, gut microflora, Haidong chicks, intestinal morphology, probiotic.

\section{Introduction}

Probiotics are defined as viable microorganisms that in sufficient amounts on reaching the intestine in an active state can exert positive health effects [1]. Several investigations have investigated the effects of probiotics such as Aspergillus spp. on animal health; in particular, they reported that poultry growth is promoted by supplementing feeds with probiotic or prebiotics [2-6]. Yet, other studies have stated that supplementation of probiotics has no effect on the health of broiler chicks [7-9].

It has been suggested that probiotics act to stimulate the production of antimicrobial substances and organic acids, protection of the villi, and absorptive surfaces against toxins produced by pathogens, as well as the stimulation of the immune system $[10,11]$.

Copyright: Lin, et al. Open Access. This article is distributed under the terms of the Creative Commons Attribution 4.0 International License (http://creativecommons.org/licenses/by/4.0/), which permits unrestricted use, distribution, and reproduction in any medium, provided you give appropriate credit to the original author(s) and the source, provide a link to the Creative Commons license, and indicate if changes were made. The Creative Commons Public Domain Dedication waiver (http://creativecommons.org/ publicdomain/zero/1.0/) applies to the data made available in this article, unless otherwise stated.
Moreover, recent papers infer that probiotics can lower serum $\mathrm{CH}$ levels and increase packed cell volume (PCV), hemoglobin $(\mathrm{Hb})$, and red blood cell $(\mathrm{RBC})$ values [5]. Ascites is a metabolic disorder and is a multi-factorial syndrome caused by the interaction between genetic, physiological, environmental, and management factors [12]. It is characterized by hypoxemia, increased workload of the cardiopulmonary system, central venous congestion, an excessive accumulation of fluid in the body coelomic cavities [13], hypertrophy of the right ventricle (RV) and a flaccid heart [14], and finally death. A high incidence of ascites can occur when the broilers are reared at high altitudes under hypoxic conditions [15]. It is estimated that $5 \%$ of broilers and $20 \%$ of roaster birds perish due to ascites and this results in significant economic loss. To this end, Solis de los Santos et al. [16] infer that broilers fed prebiotics under hypoxic conditions showed 23\% lower incidence of ascites. These results are encouraging as they offer a potential solution to the problem of rearing fowl under high altitude conditions.

We investigated the effects of the probiotic Aspergillus niger as a dietary supplement on chicks 
reared in the Qing-zang high altitude area (China), accordingly. Specifically, we assessed the blood parameters, intestinal function, and overall intestinal morphology in birds affected with ascites. We also evaluated the histology and microflora of broiler chickens impacted with this condition.

\section{Materials and Methods}

\section{Ethical approval}

All procedures were in compliance with the national laws and regulations for animal experimentation and performed in accordance with the guiding principles of Qinghai University Animal Care Committee for the care and use of experimental animals.

\section{Study period and location}

The experiment was carried-out in Xueling Haidong Chicken Breeding Farm, Huzhu County, Qinghai, China, from December 2018 to June 2019.

\section{Bird management and treatment}

All experiments were conducted in Huzhu County in Qing-Zang plateau in northwestern China, at an altitude range of 2500-3000 $\mathrm{m}$ above sea level. A total of 720, 1-day-old commercial male Haidong chicks were randomly selected and divided into six treatments, in six replicates (with 20 chicks). Treatments consisted of adding $0 \%, 0.5 \%, 0.75 \%, 1.0 \%, 1.25 \%$, and $1.5 \%$, of $A$. niger (hereafter referred to as $\mathrm{C}, \mathrm{A} 1, \mathrm{~A} 2, \mathrm{~A} 3$, $\mathrm{A} 4$, and A5, respectively, A. niger from filamentous fungus $\left(1 \times 10^{9}\right.$ spores $\left./ \mathrm{g}\right)$ to the feed of experimental animals. Diets (mash) were formulated to meet the National Research Council nutrient requirements. The chicks were fed experimental diets (Table-1) until 42 days of age (d). The ingredients and chemical compositions of the diets were analyzed using AOAC (1990) procedures. The chicks were placed in wire-floored, stainless-steel cages and kept indoors between $30^{\circ} \mathrm{C}$ and $32^{\circ} \mathrm{C}$ from 1 to 14 days, and at $24^{\circ} \mathrm{C}$ and $26^{\circ} \mathrm{C}$ from 15 to 21 days. Light was provided continuously with incandescent bulbs throughout the experimental period (5 lux). Feed and water were provided ad libitum.

\section{Blood analysis}

One bird from each replicate was randomly chosen and blood samples taken from the brachial vein on day 42 after $6 \mathrm{~h}$ of fasting. The blood samples were collected into both heparinized test tubes and non-heparinized tubes; the heparinized blood samples were centrifuged (2000 rpm for $10 \mathrm{~min}$ ) for serum separation while the blood in plain, non-heparinized tubes were stored at $-20^{\circ} \mathrm{C}$ until assayed. The following blood parameters were measured: Cholesterol $(\mathrm{CH})$, triglycerides (TG), high-density lipoprotein (HDL), and low-density lipoprotein (LDL) PCV, RBC count, white blood cell (WBC) count, and $\mathrm{Hb}$. The index of $\mathrm{PCV}, \mathrm{RBC}$, and $\mathrm{WBC}$ was determined with the use of an automated hematology analyzer (Sysmex KX-21, Kobe, Japan). Hb concentration was calculated using the cyanmethemoglobin method. The concentration of $\mathrm{CH}, \mathrm{TG}, \mathrm{HDL}$, and LDL was estimated according to the procedures outlined by the manufacturer of the diagnostic kits (BioSystems, S.A. Barcelona, Spain) and spectrophotometer apparatus.

\section{Histological analysis of the intestinal morphology}

One bird from each replicate was randomly selected on day 42, and sacrificed by cervical

Table-1: Ingredients and chemical analyses of broiler chicken diets.

\begin{tabular}{|c|c|c|c|c|c|c|}
\hline \multirow[t]{2}{*}{ Ingredients (\%) } & \multirow[t]{2}{*}{ C } & \multicolumn{5}{|c|}{ Aspergillus niger } \\
\hline & & A1 & A2 & A3 & A4 & A5 \\
\hline Yellow Corn & 52.77 & 52.77 & 52.77 & 52.77 & 52.77 & 52.77 \\
\hline Soybean meal (46\%) & 36.0 & 36.0 & 36.0 & 36.0 & 36.0 & 36.0 \\
\hline Wheat bran & 3.0 & 2.5 & 2.25 & 2 & 1.75 & 1.5 \\
\hline Soybean oil & 3.6 & 3.6 & 3.6 & 3.6 & 3.6 & 3.6 \\
\hline Limestone & 1.16 & 1.16 & 1.16 & 1.16 & 1.16 & 1.16 \\
\hline Aspergillus niger & 0 & 0.5 & 0.75 & 1.0 & 1.25 & 1.5 \\
\hline DL-Methionine & 0.2 & 0.2 & 0.2 & 0.2 & 0.2 & 0.2 \\
\hline L-Lysine & 0.02 & 0.02 & 0.02 & 0.02 & 0.02 & 0.02 \\
\hline Vitamin-mineral Premix & 1.0 & 1.0 & 1.0 & 1.0 & 1.0 & 1.0 \\
\hline Sodium chloride & 0.3 & 0.3 & 0.3 & 0.3 & 0.3 & 0.3 \\
\hline Dicalcium phosphate & 1.95 & 1.95 & 1.95 & 1.95 & 1.95 & 1.95 \\
\hline \multicolumn{7}{|l|}{ Calculated } \\
\hline ME (kcal/kg) & 2988 & 2986 & 2984 & 2982 & 2980 & 2981 \\
\hline Dry matter (\%) & 89.5 & 89.7 & 89.6 & 89.5 & 89.8 & 89.6 \\
\hline $\mathrm{CP}(\%)$ & 21.6 & 21.4 & 21.4 & 21.3 & 21.3 & 21.4 \\
\hline Fat $(\%)$ & 2.4 & 2.4 & 2.4 & 2.4 & 2.4 & 2.4 \\
\hline Methionine & 0.64 & 0.64 & 0.64 & 0.64 & 0.64 & 0.64 \\
\hline Lysine & 1.24 & 1.23 & 1.23 & 1.24 & 1.23 & 1.23 \\
\hline $\mathrm{Ca}(\%)$ & 0.98 & 0.98 & 0.98 & 0.98 & 0.98 & 0.98 \\
\hline Av. P (\%) & 0.49 & 0.49 & 0.49 & 0.49 & 0.49 & 0.49 \\
\hline
\end{tabular}

Supplied per kilogram of diet: Vitamin A, 15000 IU; Vitamin D3, 3000 IU; Vitamin E, 26 IU; Vitamin K, 2.5 mg; Vitamin B1, 2.1 mg; Vitamin B2, 5 mg; Vitamin B6, 3 mg; Vitamin B12, 6 mg; folic acid, 1 mg; biotin, $50 \mu g$; niacin, $24 \mathrm{mg}$; choline chloride, $50 \mathrm{mg}$, manganese, $45 \mathrm{mg}$, iron, $83 \mathrm{mg}$; zinc, $10 \mathrm{mg}$, copper, $0.26 \mathrm{mg}$; iodine, $1.5 \mathrm{mg}$; selenium, $1.2 \mathrm{mg}$ 
dislocation. Segments of approximately $5 \mathrm{~cm}$ of duodenum (midpoint of the pancreatic loop), jejunum (midpoint of jejunum), and ileum (after Meckel's diverticulum) were obtained before removing the entire intestinal tract. The samples were fixed in fresh $4 \%$ buffered formalin solution for $24 \mathrm{~h}$ and processed for routine paraffin embedding. Serial $4 \mu \mathrm{m}$ transverse sections were cut and stained (routine Hematoxylin and Eosin staining) for morphological evaluation. Goblet cells containing acidic and neutral mucin were counted by staining $4 \mu \mathrm{m}$ sections with alcian blue (AB) $\mathrm{pH} 2.5+$ periodic acid-Schiff reagent (PAS). Sections were examined using a light microscope (Leitz, Diaplan) connected to a PC via a Nikon digital system (Digital Sight DS-U1). Images were acquired using the NIS-Elements F version 2.10 software (Nikon Corporation, Japan) per transverse section of small intestine. Measurements were made using the Image J 1.37V software (National Institutes of Health, Bethesda, MD, USA) package. Ten well-oriented and intact crypt-villus units of each slide were measured in triplicate. Villi height was defined as the distance from villus tip to crypt junction. Crypt depth was defined as the depth of the invagination between adjacent villi. Muscle thickness was measured from the junction between the submucosal and muscular layers to the muscular layer and the tunica serosa. Intestinal wall thickness was defined as the distance from intestinal external subserosa to the junction muscular layer and submucosa. The number of AB/PAS-positive cells along the villi was expressed as the density of cells per $\mathrm{mm}^{2}$.

\section{Intestinal microflora}

The samples of cecum and ileum content (one bird from each replicate) for microbial analysis were collected by pressing the outer wall of the cut cecum and ileum to push its content into a sterile glass bottle. One gram of cecum and ileum content was blended in $9 \mathrm{~mL}$ of sterilized physiological saline solution and homogenized using a mixing bag. Subsequently, these suspensions were serially diluted from $10^{-1}$ to $10^{-6}$ using sterilized physiological saline solution. Duplicate plates per bird sample were inoculated with $100 \mu \mathrm{L}$ of suspension and anaerobically incubated at $37^{\circ} \mathrm{C}$.

Bacterial Culture and counts: Lactobacilli were anaerobically assayed using lactobacilli MRS agar (Fisher Scientific, Ottawa, Ontario, Canada) and incubated at $37^{\circ} \mathrm{C}$ for $48 \mathrm{~h}$. Bifidobacteria counts were performed using Wilkins-Chalgren agar (Oxoid, Nepean, Ontario, Canada) supplemented with glacial acetic acid $(1 \mathrm{~mL} / \mathrm{L})$ and mupirocin $(100 \mathrm{mg} / \mathrm{L})$ extracted from antimicrobial discs (Oxoid, UK). Escherichia coli bacteria were cultured on MacConkey's agar medium (Oxoid, UK). The numbers of colony-forming units from duplicate plates per bird sample were averaged and the results were expressed as log colony-forming units per gram of intestinal content.

\section{Incidence of ascites}

The incidence of ascites was determined using both the ascites mortality data tallied throughout the study along with the incidence of ascites present on the last day of the experiment. A RV/total ventricle ratio $(\mathrm{RV} / \mathrm{TV})>0.27$ was used as a cutoff point for determining the ascites status of the birds. Chickens with an RV/TV ratio $>0.27$ were considered ascitic [17].

\section{Statistical analysis}

Mean values generated from all individual data were statistically analyzed by a one-factor variance analysis using the GLM procedure of the SAS Institute (Cary, NC, USA). They were then compared using Tukey's multiple range test at $p<0.05$ if the main effect between any groups was found to be significant. Person's Chi-square test was used for the statistical evaluation of the incidence of ascites between treatment and control groups, if the main effects were significant at $\mathrm{p}<0.05$.

\section{Results}

\section{Blood parameters}

Table-2 shows the effects of $A$. niger on the $\mathrm{PCV}, \mathrm{RBC}, \mathrm{WBC}$, and $\mathrm{Hb}$ of chickens on day 42 . The PCV values of Groups A3 and A5 were higher than in Groups A1, and the control $(p<0.05)$. At the same time, Groups A4 showed higher PVC values than the control group ( $\mathrm{p}<0.05)$. Groups A1, A2, A3, and A4 displayed higher $(p<0.05)$ numbers of RBCs compared to $\mathrm{C}$. The WBC counts of all groups were not significantly different. Groups A3, A4, and A5 revealed a higher value $(p<0.05)$ than all the other groups $(p>0.05)$ regarding the $\mathrm{Hb}$ values; Group A2 was significantly different from Groups A1 and C.

\section{Serum lipid profiles}

Table- 3 shows the effects of $A$. niger on total $\mathrm{CH}$, TG, HDL, and LDL level. The serum $\mathrm{CH}$ value was significantly lower $(p<0.05)$ in Groups A2, A3, A4, and A5 when compared to the control group. In particular, a lower value was observed in Group A3 and the differences were statistically significant compared to Groups A1 and C $(\mathrm{p}<0.05)$. Lower serum TG levels were observed in Groups A3, A4, and A5, this being significantly different $(p<0.05)$ compared to the control. Regarding serum HDL levels, lower values were observed in Groups A1, A3, and A4, this value being significantly different than those observed for the control group $(\mathrm{p}<0.05)$. The LDL serum level was significantly lower $(\mathrm{p}<0.05)$ in all groups fed $A$. niger compared to the control group, and no difference $(\mathrm{p}>0.05)$ was observed between the experimental groups.

\section{Intestinal microflora}

Table-4 shows the effects of dietary $A$. niger treatments on the intestinal microbial composition of birds at days 42. The dietary administration of $A$. niger significantly decreased $(\mathrm{p}<0.05)$ the concentration of $E$. coli in the cecum compared to the control groups and in the ileum compared to Groups A1 and 
Table-2: The effect of the Aspergillus niger on the blood parameters of broiler chickens maintained under hypoxic conditions for a period of 42 days.

\begin{tabular}{|c|c|c|c|c|}
\hline Treatments & $\begin{array}{l}\text { Packed cell } \\
\text { volume (\%) }\end{array}$ & $\begin{array}{c}\text { Red blood cell } \\
\left(10^{6} \times \text { Cell } / \mathrm{mm}^{3}\right)\end{array}$ & $\begin{array}{l}\text { White blood cell } \\
\left(10^{3} \times \text { Cell } / \mathrm{mm}^{3}\right)\end{array}$ & $\begin{array}{c}\text { Hemoglobin } \\
(\%)\end{array}$ \\
\hline $\mathrm{C}$ & $47.61 \mathrm{c}$ & $3.21^{\mathrm{b}}$ & 23.41 & $104.52^{c}$ \\
\hline A1 & $50.73^{\mathrm{bc}}$ & $3.82^{\mathrm{a}}$ & 24.32 & $106.51^{c}$ \\
\hline $\mathrm{A} 2$ & $50.22^{b c}$ & $3.85^{\mathrm{a}}$ & 23.81 & $113.64^{b}$ \\
\hline A3 & $55.71^{a}$ & $3.95^{\mathrm{a}}$ & 23.64 & $125.92^{a}$ \\
\hline A4 & $52.14^{\mathrm{ab}}$ & $3.97^{a}$ & 24.15 & $127.61^{a}$ \\
\hline A5 & $56.23^{a}$ & $3.57^{\mathrm{ab}}$ & 24.16 & $122.13^{a}$ \\
\hline SEM & 1.96 & 0.125 & 0.897 & 4.080 \\
\hline $\mathrm{p}$ & 0.005 & 0.031 & 0.426 & 0.027 \\
\hline
\end{tabular}

Means within columns with different superscript letters are different per $p<0.05$

Table-3: The effect of the Aspergillus niger on serum lipid profiles of broiler chickens maintained under hypoxic conditions for a period of 42 days.

\begin{tabular}{lcccc}
\hline Treatments & $\mathbf{C H}(\mathbf{m g} / \mathbf{d l})$ & $\begin{array}{c}\text { Triglycerides } \\
(\mathbf{m g} / \mathbf{d l})\end{array}$ & $\begin{array}{c}\text { High-density lipoproteins } \\
(\mathbf{m g} / \mathbf{d l})\end{array}$ & $\begin{array}{c}\text { Low-density } \\
\text { lipoprotein }(\mathbf{m g} / \mathbf{d l})\end{array}$ \\
\hline C & $187.23^{\mathrm{a}}$ & $67.32^{\mathrm{a}}$ & $92.68^{\mathrm{a}}$ & $92.62^{\mathrm{a}}$ \\
A1 & $182.65^{\mathrm{ab}}$ & $64.64^{\mathrm{b}}$ & $85.55^{\mathrm{b}}$ & $85.54^{\mathrm{b}}$ \\
A2 & $177.97^{\mathrm{bc}}$ & $63.81^{\mathrm{ab}}$ & $88.13^{\mathrm{b}}$ & $86.33^{\mathrm{b}}$ \\
A3 & $173.33^{\mathrm{c}}$ & $61.43^{\mathrm{b}}$ & $85.26^{\mathrm{b}}$ & $87.64^{\mathrm{b}}$ \\
A4 & $175.54^{\mathrm{bc}}$ & $61.34^{\mathrm{b}}$ & $85.63^{\mathrm{b}}$ & $86.55^{\mathrm{b}}$ \\
A5 & $176.67^{\mathrm{bc}}$ & $62.87^{\mathrm{b}}$ & $87.84^{\mathrm{ab}}$ & $87.28^{\mathrm{b}}$ \\
SEM & 6.191 & 2.352 & 3.307 & 3.461 \\
p & 0.042 & 0.034 & 0.026 & 0.018 \\
\hline
\end{tabular}

Mean values within columns with different superscript letters are different per $p<0.05$

Table-4: The effect of food supplementation with Aspergillus niger on the number of intestinal microbial (log $10 \mathrm{cfu} / \mathrm{g}$ ) located in broilers on day 42 .

\begin{tabular}{lccccccc}
\hline Treatments & \multicolumn{3}{c}{ Cecum } & & \multicolumn{2}{c}{ Ileum } \\
\cline { 2 - 4 } \cline { 6 - 8 } & $\begin{array}{c}\text { Escherichia } \\
\text { coli }\end{array}$ & Bifidobacterium & Lactobacillus & & Escherichia coli & Bifidobacterium Lactobacillus \\
\hline C & $8.89^{\mathrm{a}}$ & $7.45 \pm 0.56^{\mathrm{b}}$ & $7.86 \pm 0.37^{\mathrm{b}}$ & & $7.51^{\mathrm{a}}$ & $6.06^{\mathrm{b}}$ & $7.33 \pm 0.91^{\mathrm{c}}$ \\
A1 & $8.46^{\mathrm{b}}$ & $8.23 \pm 0.33^{\mathrm{ab}}$ & $8.85 \pm 0.54^{\mathrm{a}}$ & & $7.35^{\mathrm{a}}$ & $6.26^{\mathrm{b}}$ & $8.85 \pm 0.58^{\mathrm{b}}$ \\
A2 & $7.23^{\mathrm{bc}}$ & $8.56 \pm 0.67^{\mathrm{a}}$ & $9.32 \pm 0.76^{\mathrm{a}}$ & & $6.12^{\mathrm{b}}$ & $6.24^{\mathrm{b}}$ & $8.93 \pm 0.39^{\mathrm{b}}$ \\
A3 & $7.13^{\mathrm{c}}$ & $8.69 \pm 0.56^{\mathrm{a}}$ & $9.47 \pm 0.91^{\mathrm{a}}$ & & $6.02^{\mathrm{b}}$ & $7.39^{\mathrm{a}}$ & $9.15 \pm 0.69^{\mathrm{a}}$ \\
A4 & $7.25^{\mathrm{bc}}$ & $8.65 \pm 0.76^{\mathrm{a}}$ & $9.29 \pm 0.83^{\mathrm{a}}$ & & $6.06^{\mathrm{b}}$ & $7.26^{\mathrm{a}}$ & $9.09 \pm 0.86^{\mathrm{b}}$ \\
A5 & $7.31^{\mathrm{bc}}$ & $8.57 \pm 0.62^{\mathrm{a}}$ & $9.36 \pm 0.76^{\mathrm{a}}$ & & $6.09^{\mathrm{b}}$ & $7.32^{\mathrm{a}}$ & $9.06 \pm 0.90^{\mathrm{ab}}$ \\
SEM & 0.219 & 0.238 & 0.284 & & 0.221 & 0.244 & 0.201 \\
P & 0.018 & 0.022 & 0.034 & & 0.042 & 0.029 & 0.011 \\
\hline
\end{tabular}

control. The concentration of Bifidobacterium in the cecum significantly was increased $(\mathrm{p}<0.05)$ in Groups A2, A3, A4, and A5 compared to the control group. The concentration of Bifidobacterium in the ileum was increased $(\mathrm{p}<0.05)$ in Groups A3, A4, and A5 compared to Groups A1, A2, and control. The dietary administration of $A$. niger significantly increased $(\mathrm{p}<0.05)$ the concentration of Lactobacillus in the cecum. Lactobacillus counts in the ileum were significantly increased in Groups A2, A3, A4, and A5, compared to the control group, and the peak number appeared in Group A3 ( $\mathrm{p}<0.05)$.

\section{Intestinal morphology and the incidence of ascites}

Table-5 shows the effects of dietary addition of A. niger on the height of intestinal villus and depth of crypt in broiler chickens on day 42. Groups A3 and A4 had higher duodenum and ileum villi compared to the other groups $(\mathrm{p}<0.05)$. However, Groups A2,
A3, and A4 had higher villi in the jejunum compared to the other groups $(\mathrm{p}<0.05)$. Duodenum crypt depth increased in Groups A3, A4, and A5 compared to the other groups $(p<0.05)$. Jejunum and ileum crypt depth also increased significantly in Groups A2, A3, A4, and A5 compared to Groups A1 and control $(p<0.05)$.

Table- 6 shows the effects of dietary addition of A. niger on the density of goblet cells in the intestine and on the incidence of ascites. Goblet cell density in the duodenum, jejunum, and ileum was highest in Groups A3, A4, and A5 compared to Groups A1 and control $(p<0.05)$. Similarly, the difference in goblet cell density in Groups A1 and A2, compared to the control group, was significant $(\mathrm{p}<0.05)$.

It was clear that all groups fed with $A$. niger showed significantly lower values compared to the control $(p<0.05)$ regarding the incidence of ascites in broilers. Interestingly, no differences were observed between any of the experimental Groups A1-A5 ( $\mathrm{p}>0.05)$. 
Table-5: The effect of the Aspergillus niger food supplementation on the height of intestinal villus and depth of crypt in 42 day-old broilers.

\begin{tabular}{|c|c|c|c|c|c|c|}
\hline \multirow[t]{2}{*}{ Treatments } & \multicolumn{3}{|c|}{ The height of intestinal villus ( $\mu \mathrm{m})$} & \multicolumn{3}{|c|}{ The depth of crypt $(\mu \mathrm{m})$} \\
\hline & Duodenum & Jejunum & Ileum & Duodenum & Jejunum & Ileum \\
\hline C & $1943.6^{\mathrm{b}}$ & $1351.92^{\mathrm{b}}$ & $731.53^{b}$ & $158.91^{\mathrm{b}}$ & $149.88^{b}$ & $113.81^{\mathrm{b}}$ \\
\hline A1 & $1936.8^{\mathrm{b}}$ & $1345.62^{b}$ & $732.32^{\mathrm{b}}$ & $165.35^{\mathrm{b}}$ & $156.22^{\mathrm{b}}$ & $120.15^{b}$ \\
\hline $\mathrm{A} 2$ & $1941.4^{b}$ & $1465.34^{\mathrm{a}}$ & $723.44^{b}$ & $167.23^{b}$ & $192.49^{a}$ & $152.32^{\mathrm{a}}$ \\
\hline A3 & $1982.6^{a}$ & $1456.76^{\mathrm{a}}$ & $778.68^{\mathrm{a}}$ & $206.78^{\mathrm{a}}$ & $195.71^{\mathrm{a}}$ & $155.67^{a}$ \\
\hline A4 & $1984.5^{a}$ & $1472.33^{\mathrm{a}}$ & $773.26^{\mathrm{a}}$ & $188.42^{\mathrm{a}}$ & $192.14^{a}$ & $153.24^{a}$ \\
\hline A5 & $1928.4^{b}$ & $1360.57^{b}$ & $735.75^{b}$ & $191.69^{a}$ & $194.38^{a}$ & $154.61^{a}$ \\
\hline SEM & 40.636 & 51.714 & 26.952 & 6.531 & 6.054 & 5.197 \\
\hline $\mathrm{p}$ & 0.041 & 0.029 & 0.034 & 0.014 & 0.011 & 0.016 \\
\hline
\end{tabular}

Means within columns with different superscript capital letters at same day are different $(p<0.05)$

Table-6: The effect of the Aspergillus niger on the density of goblet cells in intestine and the incidence of ascites in broiler chickens maintained under hypoxic conditions for 42 days.

\begin{tabular}{lcccc}
\hline Treatments & \multicolumn{3}{c}{ Goblet cell (cells/villus) } & Ascites incidence (\%) \\
\cline { 2 - 4 } & Duodenum & Jejunum & Ileum & \\
\hline C & $59.84 \pm 11.1^{\mathrm{c}}$ & $59.84 \pm 11.1^{\mathrm{c}}$ & $58.75 \pm 18.2^{\mathrm{c}}$ & $65.74 \pm 6.16^{\mathrm{a}}$ \\
A1 & $67.56 \pm 6.25^{\mathrm{bc}}$ & $82.54 \pm 6.54^{\mathrm{b}}$ & $70.32 \pm 7.25^{\mathrm{b}}$ & $54.21 \pm 5.21^{\mathrm{b}}$ \\
A2 & $78.45 \pm 7.85^{\mathrm{ab}}$ & $86.23 \pm 7.25^{\mathrm{b}}$ & $89.12 \pm 8.76^{\mathrm{b}}$ & $52.45 \pm 4.88^{\mathrm{b}}$ \\
A3 & $82.64 \pm 8.01^{\mathrm{a}}$ & $97.26 \pm 9.64^{\mathrm{a}}$ & $103.45 \pm 12.20^{\mathrm{a}}$ & $53.83 \pm 6.12^{\mathrm{b}}$ \\
A4 & $90.35 \pm 8.87^{\mathrm{a}}$ & $97.56 \pm 8.79^{\mathrm{a}}$ & $98.68 \pm 10.71^{\mathrm{a}}$ & $51.26 \pm 5.32^{\mathrm{b}}$ \\
A5 & $87.32 \pm 7.56^{\mathrm{a}}$ & $96.33 \pm 9.27^{\mathrm{a}}$ & $101.34 \pm 11.24^{\mathrm{a}}$ & $52.92 \pm 5.88^{\mathrm{b}}$ \\
SEM & 3.376 & 3.577 & 4.651 & 2.283 \\
p & 0.018 & 0.011 & 0.013 & 0.037 \\
\hline
\end{tabular}

Means within columns with different superscript capital letters at same day are different $(p<0.05)$

\section{Discussion}

Blood parameters (PCV, RBC, WBC, and $\mathrm{Hb}$ ) were positively affected by the addition of $A$. niger to the diet of broiler chickens in this study. These results are in agreement with those observed by AI-Kassie et al. [5], who indicated that probiotic supplementation increased $\mathrm{Hb}$ values. It is reasonable to surmise that broilers have considerable difficulty meeting the oxygen demand required to maintain healthy tissue when hypoxia occurs. The addition of probiotics added to their feed seems to enhance growth performance by improving blood oxygen saturation, RBC production (partially immature), and $\mathrm{Hb}$ content [17]. Yet, Alkhalf et al. [18] found that probiotic diet supplementation did not cause significant increases in the erythrocyte count, $\mathrm{Hb}$ concentration, or hematocrit values of broilers. This could potentially be explained by the characteristics (type and number of species) of the probiotics employed in the different treatment regimes.

Our findings showed that the supplementation of broiler diets with $A$. niger significantly affected serum lipid profiles by decreasing serum $\mathrm{CH}, \mathrm{TG}, \mathrm{HDL}$, and LDL levels. These results confirmed the findings of Al-Kassie et al. [5]. They suggested that there is a significant reduction in serum total CH levels in broilers fed with A. niger. Similar results have also been described by Yoon et al. [19]. According to these authors, hypocholesterolemia in broiler chickens was positively affected by the supplementation of ß-fructans from chicory as a source of probiotics. Furthermore, Zhu et al. [20], Saleh et al. [21], Al-Kassie et al. [5], and Saleh et al. [22] all agree that the reduction of serum $\mathrm{CH}$ levels could be due to the $\mathrm{CH}$ assimilation by Lactobacillus. Probiotic and prebiotic diet supplementation might enhance the lactobacilli count as well as the reduction of $\mathrm{pH}$ in the intestinal tract in this perspective.

The beneficial effects of probiotics on host indigenous microflora are well known [23]. This study indicates that the dietary administration of $1.0 \%$ and $1.25 \%$ of $A$. niger significantly decreased the concentration of $E$. coli in the cecum, while increasing the concentration of Bifidobacterium and Lactobacillus both in the cecum and ileum. Ohimain and Ofongo [23] reported a significant variation in relative amounts of bifidobacteria and lactobacilli in the intestinal content between the treatment groups, with generally more bifidobacteria produced with increased probiotic content.

Histological evaluation of the intestinal morphology has become a valuable tool in the assessment of developmental changes under different dietary conditions [24,25].

Increasing the villus height suggests an increased surface area capable of greater absorption of available nutrients. The villi play a crucial role in the digestion and absorption processes of the small intestine, as they increase the surface area and are the first to make contact with nutrients within the lumen [25]. Our observations demonstrated that a diet supplemented with $1.0 \%$ A. niger increased villi height 
in the duodenum, jejunum, and ileum of chickens. Several researchers have reported similar results. In one study, Awad et al. [26] found that a $0.1 \%$ probiotic supplementation appeared to increase villi heights in the duodenum and ileum. Awad et al. [27] described these alterations in the mucosal architecture in terms of increased ileal villus height in birds fed with a $0.1 \%$ symbiotic supplemented diet. Moreover, Pelicano et al. [28] showed that the addition of $0.1 \%$ probiotics to the diet resulted in longer jejunal and ileum villi in chickens. Furthermore, an increase in the villus length and width of the duodenum and ileum of broiler chickens treated with $0.1 \%$ prebiotic was reported by Sayrafi et al. [29].

Schwarz et al. [30] did not observe differences in crypt depth of the jejunum between the control group and the birds receiving diets containing Bacillus subtilis, but higher crypt depth was determined when probiotics based on Lactobacillus fermentum were used. Pelicano et al. [28] did not see differences in crypt depth in the ileum between the control groups and the groups receiving diets containing probiotics. This study demonstrated that the addition of $1.0 \%$ $A$. niger to the diet increased crypt depth in the duodenum, jejunum, and ileum of chicken on days 21 . These findings corroborate the results regarding crypt depth described by Pelicano et al. [28] when probiotics were added to the diet.

Although Mair et al. [31] found that the density of acidic goblet cells in jejunal villi significantly decreased with the application of prebiotics to piglet diets, the current study demonstrated that the number of goblet cells in the duodenum, jejunum, and ileum increased by feeding $0.5 \%-1.5 \% \mathrm{~A}$. niger to chickens. The improvement in crypt depth and density of goblet cells observed in probiotic-treated birds may be due to the rapid crypt maturation to ensure an adequate epithelium turnover rate, thus compensating for the losses [28].

Ascites syndrome in broilers is attributed to a higher metabolic burden which may lead to metabolic hypoxia or low efficiency of oxygen utilization. It is particularly severe when animals are raised in high altitude environments [16]. Our data indicate that the reduction of ascites incidence may be due to the probiotic treatment which increases the level of several blood parameters (RBC and $\mathrm{Hb}$, overall). To this end, Solis de los Santos et al. [16] reported that broilers have difficulties in fulfilling tissue demands for oxygen in the case of hypoxia; thus, they exhibit a decrease in blood saturation and an increase in RBC production (partially immature). Simultaneously, a reduction in $\mathrm{Hb}$ content in $\mathrm{RBCs}$ might potentiate hypoxemia and the aggravation of ascites.

\section{Conclusion}

Our results indicate that the inclusion of $A$. niger in diets of broilers, at a ratio ranging between $1.0 \%$ and $1.25 \%$, enhances growth performance, blood parameters, intestinal morphology, and intestinal microflora. A reduction in serum $\mathrm{CH}$ level, E. coli in intestine, and ascites incidence was also observed. Collectively, these findings suggest that $A$. niger improves the resistance of chickens to hypoxic conditions. Moreover, the employment of probiotics is a viable alternative to the use of antibiotics in the agricultural production of broiler chickens. It represents an important step not only in increasing the environmental sustainability of broiler production but it is also a way of enhancing consumer safety. It is with this concern that we suggest further investigation into the interactions between the use of prebiotics and probiotics in birds raised under hypoxic conditions.

\section{Authors' Contributions}

HL: He is a master student who did most part of the research, contributed in, data collection, analysis, and manuscript. BD: Designed the research, method, data collection, and manuscript. LC: Data collection, analysis, and manuscript drafting. ZZ: Directed in method and data collection. HH: Directed in method and data collection. JW: Directed in method and data collection. XW: Directed in method and data collection. LZ: Directed in method and data collection. XN: Directed in method and data collection. BF: Designed the research, method, data collection, and manuscript. All authors read and approved the final manuscript.

\section{Acknowledgments}

This study was supported by grants from the Science and Technology Department of Qinghai Province (Grant No. 2019-HZ-812) and the National Natural Science Foundation of China (Grant No. 31160463). The authors express their appreciation to the Qinghai Huzhu Xuelin Farm (Qinghai, China) for the use of animals and for their assistance with animal care and feeding protocols throughout this study. We also thank the staff at the Qinghai Animal Disease Control Center (Qinghai, China) for sample analyses.

\section{Competing Interests}

The authors declare that they have no competing interests.

\section{Publisher's Note}

Veterinary World remains neutral with regard to jurisdictional claims in published institutional affiliation.

\section{References}

1. Kim, Y.A., Keogh, J.B. and Clifton, P.M. (2017) Probiotics, prebiotics, synbiotics and insulin sensitivity. Nutr. Res. Rev., 31(1): 35-51.

2. Elmi, V.A., Moradi, S., Ghazi, S. and Rahimi, M. (2020) Effects of Lactobacillus acidophilus and natural antibacterials on growth performance and Salmonella colonization in broiler chickens challenged with Salmonella enteritidis. Livest Sci., 233(3): 103948.

3. Hajimohammadi, A., Mottaghitalab, M. and Hashemi, M. (2020) Effects of microbial fermented sesame meal and 
enzyme supplementation on the intestinal morphology, microbiota, $\mathrm{pH}$, tibia bone and blood parameters of broiler chicks. Ital. J. Anim. Sci., 19(1): 457-467.

4. Aalaei, M., Khatibjoo, A., Zaghari, M., Taherpour, K., Gharaei, M.A. and Soltani, M. (2018) Comparison of single-and multi-strain probiotics effects on broiler breeder performance, egg production, egg quality and hatchability. Br. Poult. Sci., 59(5): 531-538.

5. Al-Kassie, G.A.M., Al-Jumaa, Y.M.F. and Jameel, Y.J. (2008) Effect of probiotic (Aspergillus niger) and prebiotic (Taraxacum officinale) on blood picture and biochemical properties of broiler chicks. Int. J. Poult. Sci., 7(12): 1182-1184.

6. Awais, M.M., Jamal, M.A., Akhtar, M., Hameed, M.R., Anwar, M.I. and Ullah, M.I. (2019) Immunomodulatory and ameliorative effects of Lactobacillus and Saccharomyces based probiotics on pathological effects of eimeriasis in broilers. Microb. Pathog., 126(1): 101-108.

7. Noohi, N., Ebrahimipour, G., Rohani, M., Talebi, M. and Pourshafie, M.R. (2016) Evaluation of potential probiotic characteristics and antibacterial effects of strains of Pediococcus species isolated from broiler chickens. $\mathrm{Br}$. Poult. Sci., 57(3): 317-323.

8. Majidi-Mosleh, A., Sadeghi, A.A., Mousavi, S.N., Chamani, M. and Zarei, A. (2017) Ileal MUC2 gene expression and microbial population, but not growth performance and immune response, are influenced by in ovo injection of probiotics in broiler chickens. Br. Poult. Sci., 58(1): 40-45.

9. Chamberlain, C.A., Hatch, M. and Garrett, T.J. (2019) Metabolomic profiling of oxalate-degrading probiotic Lactobacillus acidophilus and Lactobacillus gasseri. PLoS One, 14(9): e0222393.

10. Fathi, M.M., Ebeid, T.A., Al-Homidan, I., Soliman, N.K. and Abou-Emera, O.K. (2017) Influence of probiotic supplementation on immune response in broilers raised under hot climate. Br. Poult. Sci., 58(5): 512-516.

11. Yadav, A.K., Tyagi, A., Kumar, A., Panwar, S., Grover, S., Saklani, A.C., Hemalatha, R. and Batish, V.K. (2017) Adhesion of lactobacilli and their anti-infectivity potential. Crit. Rev. Food Sci. Nutr., 57(10): 2042-2056.

12. Afolayan, M., Abeke, F.O. and Atanda, A. (2016) Ascites versus sudden death syndrome (SDS) in broiler chickens: A review. J. Anim. Prod. Res., 28(2): 76-87.

13. Owen, R.L., Wideman, R.F., Hattel, A.L. and Cowen, B.S (1990) Use of a hypobaric chamber as a model system for investigating ascites in broilers. Avian Dis., 34(3): 754-758.

14. Riddell, C. (1991) Developmental, Metabolic and Miscellaneous Disorders. Disease of Poultry. 9 $^{\text {th }}$ ed. Iowa State University Press, Ames, IA. p839-841.

15. Wideman, R.F., Hooge, D.M. and Cummings, K.R. (2003) Dietary sodium bicarbonate, cool temperatures, and feed withdrawal: Impact on arterial and venous blood-gas values in broilers. Poult. Sci., 82(4): 560-570.

16. Santos, F.S.L., Farnell, M.B., Tellez, G., Balog, J.M., Anthony, N.B., Torres-Rodriguez, A., Higgins, S., Hargis, B.M. and Donoghue, A.M. (2005) Effect of prebiotic on gut development and ascites incidence of broilers reared in a hypoxic environment. Poult. Sci., 84(7): 1092-1100.

17. Pavlidis, H.O., Balog, J.M., Stamps, L.K., Hughes, J.D. and Anthony, N.B. (2007) Divergent selection for ascites incidence in chickens. Poult. Sci., 86(12): 2517-2529.

18. Alkhalf, A., Alhaj, M. and Al-Homidan, I. (2010) Influence of probiotic supplementation on blood parameters and growth performance in broiler chickens. Saudi J. Biol. Sci., 17(3): 219-225.

19. Yoon, C., Na, C.S., Park, J.H., Han, S.K. and Kwon, J.T. (2004) Effect of feeding multiple probiotics on performance and fecal noxious gas emission in broiler chicks. Korea $J$. Poult. Sci., 31(4): 229-235.

20. Zhu, C., Wang, L., Wei, S.Y., Chen, Z., Ma, X.Y., Zheng, C.T. and Jiang, Z.Y. (2017) Effect of yeast Saccharomyces cerevisiae supplementation on serum antioxidant capacity, mucosal sIgA secretions and gut microbial populations in weaned piglets. J. Integr. Agric., 16(9): 2029-2037.

21. Saleh, A.A., Gálik, B., Arpášová, H., Capcarová, M., Kalafová, A., Šimko, M., Juráček, M., Rolinec, M., Bíro, D. and Abudabos, A.M. (2017) Synergistic effect of feeding Aspergillus awamori and lactic acid bacteria on performance, egg traits, egg yolk cholesterol and fatty acid profile in laying hens. Ital. J. Anim. Sci., 16(1): 132-139.

22. Saleh, A.A., Hayashi, K., Ijiri, D. and Ohtsuka, A. (2015) The influence of dietary supplementation with Aspergillus awamori and feeding canola seed on the growth performance and meat quality in male broilers chickens. J. Anim. Sci., 86(3): 305-311.

23. Ohimain, E.I. and Ofongo, R.T.S. (2012) The effect of probiotic and prebiotic feed supplementation on chicken health and gut microflora: A review. J. Anim. Vet. Adv., 4(2): 135-143.

24. Mirzaie, S., Sharifi, S.D. and Zirak-Khattab, F. (2020) The effect of a Chlorella by-product dietary supplement on immune response, antioxidant status, and intestinal mucosal morphology of broiler chickens. J. Appl. Phycol., 32(4): 1771-1777.

25. Ding, B.A., Pirone, A., Lenzi, C., Baglini, A. and Romboli, I. (2011) Effect of hen diet supplemented with 25-OH-D 3 on the development of small intestinal morphology of chick. J. Anim. Feed Sci., 20(3): 420-431.

26. Awad, W.A., Ghareeb, K., Abdel-Raheem, S. and Böhm, J. (2009) Effects of dietary inclusion of probiotic and synbiotic on growth performance, organ weights, and intestinal histomorphology of broiler chickens. Poult. Sci., 88(1): 49-56.

27. Awad, W., Ghareeb, K. and Böhm, J. (2008) Intestinal structure and function of broiler chickens on diets supplemented with a synbiotic containing Enterococcus faecium and oligosaccharides. Int. J. Mol. Sci., 9(11): 2205-2216.

28. Pelicano, E.R.L., Souza, P.A., Souza, H.B.A., Oba, A., Norkus, E.A., Kodawara, L.M. and Lima, T.M.A. (2003) Intestinal Mucosa Structure and Ultrastructure in Broilers fed with Diets supplemented with different Probiotics. Rev. Bras. Cien. Avicola, 98(547): 124-134.

29. Sayrafi, R., Shahrooz, R., Soltanalinejad, F. and Rahimi, S. (2011) Histomorphometrical study of the prebiotic effects on intestine morphology and growth performance of broiler chickens. Vet. Res. Forum, 2(1): 45-51.

30. Schwarz, K.K., Franco, S.G., Fedalto, L.M., Borges, S.A., Fisher da Silva, A.V. and Pedroso, A.C. (2002) Effects of antimicrobials, probiotics, prebiotics and symbiotics on the performance and morphology of chicken jejunum. Braz. J. Poult. Sci., 4(4): 75.

31. Mair, C., Plitzner, C., Pfaffl, M.W., Schedle, K., Meyer, H.H.D. and Windisch, W. (2010) Inulin and probiotics in newly weaned piglets: Effects on intestinal morphology, mRNA expression levels of inflammatory marker genes and haematology. Arch. Anim. Nutr., 64(4): 304-321. 